ELORE (ISSN 1456-3010), vol. 15 - 1/2008.

Julkaisija: Suomen Kansantietouden Tutkijain Seura ry.

[http://www.elore.fi/arkisto/1_08/fhl1_08.pdf]

\title{
SAATTEEKSI:
}

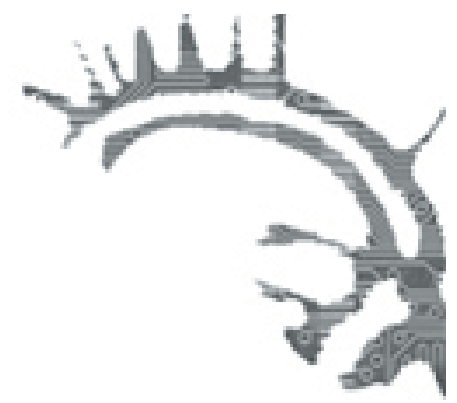

\section{IKÄ ON ALITEORETISOITU ERO}

\author{
Outi Fingerroos, Tuija Hovi, Merja Leppälahti ja Helena Saarikoski
}

Perinteentutkimuksen alkuvaiheissa nähtiin tutkimuksen kohde, yleensä perinneteksti, jollakin tavoin toimijoista irrallisena ilmiönä. Toki perinteen kerääjät tiesivät, että eri-ikäisillä on erityiset laulunsa lapsista vanhuksiin, "erittäin pojilla, erittäin tytöillä, erittäin miehillä, erittäin naisilla, erittäin ukoilla, erittäin akoilla.” (Lönnrot 1997, VLI.) Kansanperinne kuitenkin tulkittiin mielellään "kansan" yhteiseksi henkiseksi perinnöksi, ei millekään erityisryhmälle kuuluvaksi. (Esim. Hautala 1954, 8-24.) Nykyään pidetään lähes itsestään selvänä, että monet käytänteet ovat eri-ikäisillä selvästi erilaisia ja että ikäryhmän huomioon ottaminen kuuluu hyvään tutkimuskäytäntöön.

Tässä Eloren teemanumerossa paneudutaan nimenomaan eri-ikäisiin toimijoihin. Teksteissä tarkastellaan eri ikäkausiin liittyvää tutkimusta nostaen esille varsinkin kotimaiseen perinteentutkimukseen liittyviä näkökulmia. Pyrkimyksenä on valottaa erilaisia tapoja lähestyä tutkimuksellisesti tiettyjä ikäkausia sekä niitä erityispiirteitä ja haasteita, joita näihin tutkimusalueisiin liittyy. Pääosa kirjoittajista on folkloristeja ja perinteentutkijoita.

\section{IKÄRYHMÄT JA SUKUPOLVET}

Suomen kielessä sanat sukupolvi ja ikäryhmä ovat lähes synonyymeja. Tutkimuksellisina käsitteinä ne saavat kuitenkin erilaisia sisältöjä: ikäryhmä on rakenteellinen ilmiö, kun taas sukupolvi viittaa historiallisiin ilmiöihin. Sosiologi Semi Purhosen (2007) mukaan sukupolvi liittyy läheisesti ajan hengen käsitteeseen. Sukupolven käsitteen avulla pyritään määrittämään, jopa ohjaamaan, mikä kulttuurissa on tietyllä hetkellä keskeistä. Sukupolvi on siten määrityksistä ja luokituksista käytävän neuvottelun, taistelun tulos. Käsite on myös elitistinen valtapositio: ajatus sukupolvelle äänen antavasta etujoukosta tuottaa automaattisesti vastinparikseen jotkut muut, kuten saman ikäluokan "massan”, joita etujoukon väitetään kuitenkin edustavan.

Sukupolvikokemus syntyy menneisyyden representaatioista tässä hetkessä. Karl Mannheimin kokemuksellisen sukupolven käsitemalli lähtee liikkeelle siitä, että 


\section{IKÄ ON ALTTEORETISOITU ERO}

samanikäisten polvea - siis jotakin ikäluokkaa - yhdistää jokin avainkokemus, kuten yhteiskunnallinen murros, joka luo kokemuksellista samuutta ja yhteenkuuluvuutta. Samanikäisyys sinänsä ei siis riitä siteen syntymiseen, vaan tarvitaan jokin yhdessä eletty avainkokemus. Näin syntyy kokemuksellinen sukupolvi. (Mannheim 1952 teoksessa Virtanen 2001, 22-23, 30.) Folkloristi Sven-Erik Klinkmannin kolumnissaan kuvaama rock-musiikki näyttäytyy juuri edellä kuvatun kaltaisena ikäryhmäilmiönä, nuorten "kapinallisuuden" muotona, joka on ajan kuluessa muuttunut suurten ikäluokkien sukupolvikokemukseksi ja äänimaisemaksi. Talvi- ja jatkosodan kokeneiden ikäluokkien, etenkin veteraanien ja sïrtokarjalaisten, sukupolvikokemuksia on hyödynnetty monenlaisista valtapositioista käsin.

Ikäryhmä ja sukupolvi ovat siis tieteellisinä käsitteinä eri asioita. Esimerkiksi nuorten tai lasten tutkiminen tulevaisuuden airuina, joka on yksi tapaus Sinikka Vakimon kuvaamasta tutkimuksen vääristyneestä ikäparadigmasta, voi viedä harhaan tästä syystä: kyse voikin olla ikäryhmän kulttuurista tässä historiallisessa tilanteessa, ei uudenlaisesta sukupolvesta, joka tulee viemään kulttuurinsa mukanaan siirtyessään tulevaisuudessa vanhempiin ikäryhmiin.

\section{IKÄKAUSITUTKIMUKSEN LAPSET, NUORET JA VANHUKSET}

Ikäkausitutkimuksen kolme alaa, lapsi-, nuoriso- ja vanhuustutkimus, ovat teemanumerossa edustettuna katsauksin ja katsausartikkelein. Folkloristi Reeli Karimäen katsaus "Näkökulmia 2000-luvun suomalaiseen lapsuuteen" johdattaa varhaisimman ikäkauden pariin yhteiskunta- ja perinnetieteellisessä tutkimuksessa. Karimäki paitsi selventää, mikä on lapsen paikka tämänhetkisessä lapsitutkimuksessa, myös pohtii lapsen osallisuutta tutkimusprosessissa. Lapsi on lapsitutkimuksessa subjekti, jolla on tutkimuksessa oikeus ja halu tuoda esille oma asemansa ja omia näkökulmiaan. Karimäki pohtii katsauksessaan niin ikään lapsitutkimuksen eettisiä kysymyksiä: sitä, mitä on otettava huomioon tutkittaessa nimenomaan tätä ikäryhmää.

Folkloristi Merja Leppälahden katsauksessa "Silmäys nuorisotutkimukseen" siirrytään seuraavaan ikäkauteen. Leppälahti valottaa poikki- ja monitieteellistä nuorisotutkimuksen kenttää, jonka pohjana ovat olleet 1950-1960-luvuilla tuotetut jengi- ja alakulttuuritutkimukset. Nämä oman aikansa poikatutkimukset avasivat tietä myös myöhemmälle lapsi- ja tyttötutkimukselle. Leppälahti osoittaa, kuinka liukuva käsite nuoruus tutkimuksen käsissä on, sekä tuo esiin sen, että nuoriso ei ole homogeeninen ryhmä - kuten eivät muutkaan ikäryhmät tai sukupolvet. Suomessa nuorisotutkimusta on tehty sosiologian ja perinteentutkimuksen kentillä.

Folkloristi Karoliina Ojanen tarkastelee katsausartikkelissaan nuorisotutkimuksen erityisaluetta, tyttötutkimusta. Folkloristisen tyttötutkimuksen alkaminen liittyy toisaalta lapsilähtöiseen lapsuustutkimukseen, toisaalta naistutkimukseen. Ojanen esittelee sekä folkloristisen että sosiologisen tyttötutkimuksen linjoja ja kuvaa tapoja, joilla tyttötutkimuksen eri vaiheissa on tyttöjä ja tyttökulttuureita pyritty nostamaan esille. Usein tyttötutkimuksen keskeisenä tarkoituksena on nähty tyttöjen voimaan- 


\section{Outi Fingerroos, Tuija Hovi, Merja Leppälahti ja Helena Saarikoski}

nuttaminen. Välillä on korostettu feminiinisten piirteiden positiivista arvoa, toisinaan haluttu kuvata vahvoja ja pärjääviä tyttöjä. Nykyään tyttöjen kulttuurit nähdään itsessään tutkimisen arvoisiksi ja tutkimuksissa halutaan tuoda näkyviin tyttöyden ja tyttökulttuurien erilaisuutta ja moninaisuutta.

Kulttuurinen luovuus yhdistetään usein nuoruuteen, mutta aktiivisia toimijoita löytyy myös vanhemmista ikäluokista, vakuuttaa perinteentutkija Sinikka Vakimo. Katsausartikkelissaan hän yhdistää kriittisesti folkloristiikan oppihistorian ja ikäkausien määrittämän ihmiskuvan tarkastelun ja toteaa, että vaikka folkloristisen tutkimuksen alkuvaiheissa informanteiksi usein aivan tarkoituksella valittiin iäkkäitä ihmisiä, nämä nähtiin lähinnä passiivisina perinteen säilyttäjinä. Paradigman vaihdoksesta huolimatta näyttää edelleen siltä, että folkloristisissakin tutkimuksissa tarkastellaan helposti vain nuorisoa uutta kulttuuria tuottavana ja tulevaisuuteen suuntautuvana ryhmänä, kun taas vanhukset nähdään pelkästään menneen muistajina ja muistelijoina, taaksepäin katsojina.

\section{NUORET MUSLIMINAISET JA TALLITYTÖT}

Nuorten naisten ja tyttöjen ikäryhmää tarkastellaan teemanumerossa myös kahdessa etnografista materiaalia hyödyntävässä artikkelissa, jotka sijoittuvat hyvin erilaisiin kulttuurisiin konteksteihin. Artikkeleita yhdistää valtakokemusten tarkastelu suhteessa sukupuoleen. Tukholmalaisen etnologin Pia Karlsson Mingantin artikkeli "Becoming a 'Practicing' Muslim - Reflections on Gender, Racism and Religious Identity among Women in a Swedish Muslim Youth Organisation" on Ruotsiin lapsena muuttaneiden nuorten musliminaisten kanssa tehtyyn kenttätyöhön perustuva tutkimus islamistisen identiteetin rakentamisesta. Karlsson Minganti tarkastelee identiteettiä useiden erojen leikkauspintana. Nuorten naisten kertomuksista on luettu avainskenaario teini-iän kriisistä, joka on koskettanut ennen kaikkea sukupuolta, "rotua"/kansallisuutta ja uskontoa. Naiset ovat ensimmäisen polven maahanmuuttajia, jotka ovat rakentaneet identiteettiään erityisenä musliminaisen sukupolvikokemuksena 2000-luvun vaihteen Ruotsissa. Karlsson Minganti kuvaa nuorten naisten monentasoista kriisiä vähemmistöryhmän sisäisen ja ulkoisen rasismin ja seksismin paineissa. Islamistinen herääminen näyttäytyy tienä ulos sorrosta, kulttuuriseen kiistämiseen ja traditioiden neuvottelemiseen valtaannuttavana.

Folkloristi Karoliina Ojanen puolestaan tutkii omassa artikkelissaan "Kenttäkokemuksesta tiedoksi” tallityttöyhteisön sosiaalista rakennetta ja kulttuurista tilaa valtaa ja hierarkiaa ilmentävinä kategorioina. Tutkija palaa teinivuosiensa tuttuun harrastemiljööseen nyt osallistuvana havainnoitsijana. Aiempien omien tallityttökokemustensa kautta hän lähestyy ulkopuolisuuden ja osallisuuden asemoitumista tutkimassaan yhteisössä. Yhtäl̈lä tutkijana, toisaalta tallitytönkin roolin tuntevana Ojanen pohtii refleksiivistä paikantumista omia positioitaan analysoimalla. Sitä kautta avautuu ovi yhden ikäkauteen sidotun sisäpiirin sosiaaliseen maailmaan. 


\section{IKÄ ON ALTTEORETISOITU ERO}

\section{UNOHDETUT AIKUISET}

Ikäkausitutkimus kohdistuu usein erilaisiin marginaalisiin ryhmiin unohtaen aikuiset. Kolumnissaan "I ålderskategoriernas grepp" folkloristi Sven-Erik Klinkmann avaa epäsuhtaista asetelmaa. Voi nimittäin ajatella, että ikäkausitutkimus on itse marginalisoimassa kohteitaan; aikuisuus määrittyy normaaliuden lähtökohdaksi, kun tutkijat itse ovat aikuisia.

Klinkmannin kolumnia voi melkeinpä pitää pohdiskelevana katsauksena, sillä hän käsittelee Sinikka Vakimon tavoin yleisemmällä tasolla ikäkategorioita ja ikäkausitutkimuksen kysymyksiä. Klinkmannin ja Vakimon tekstejä yhdistääkin muutama teema, kuten aikaprojektion suhde ikäkategorioihin. Klinkmann muotoilee tämän niin, että nuoret ovat parhaiten synkroniassa oman aikansa kanssa, ja mitä vanhempi ihminen on, sitä enemmän hän ikään kuin jätättää omaa aikaansa. Vakimo puhuu teknisemmin vääristyneestä ikäparadigmasta (ks. edeltä). Vakimo vanhuustutkijana näkeekin vääristymän ennen kaikkea vanhojen ihmisten tutkimuksessa, mutta myös lapsuuden tutkijat ovat huolissaan siitä, että lapsia ja nuoria tutkitaan ikään kuin jonkin tulevaisuuden edustajina, esimerkiksi kehitysnäkökulmasta, sen sijaan, että annettaisiin arvo lasten elämälle lapsuutena ja tutkittaisiin esimerkiksi lapsuutta tietyssä kulttuurissa

\section{IKÄ ON VAATIVA KATEGORIA}

Ikä on tutkimuksessa usein sivuutettu, aliteoretisoitu ero, jos sitä vertaa esimerkiksi sukupuoleen (ks. Leppäsen ja Saarikosken projektikuvaus tässä teemanumerossa). Niin sanottu intersektionaalinen tutkimus, jota esimerkiksi Pia Karlsson Mingantin artikkeli tässä numerossa edustaa, on yleensä ensi sijassa sukupuolijärjestyksen tutkimusta, jossa otetaan huomioon "toisia eroja", kuten luokka, uskonto, rotu, kansallisuus, vammaisuus tai ikä.

Sinikka Vakimo on pyrkinyt väitöskirjassaan Paljon kokeva, vähän näkyvä (2001) ottamaan sukupuolen ja iän huomioon yhtäläisinä eroina, jotka kuitenkin samalla määrittävät ihmistä eri tavoin. Huomion eri erojen erilaisesta rakentumisesta voi yleistää. Ikäkausiteemanumeron kunniaksi voi pohtia sitä, minkälainen ero juuri ikä on kulttuuristen kategorioidemme joukossa. Vakimo käyttää termiä "ikä- ja sukupuolijärjestys" tarkoittamaan sitä, miten sukupuolen ja iän yhteen kietoutuva esitys määrittyy kulttuurissa. Sukupuoliero on kansanomaisen ajattelun mukaan ehdottoman kahtia jakava ja pysyvä: ihmisen ajatellaan työstävän vain jompaakumpaa kahdesta sukupuolesta omanaan läpi elämän. Sen sijaan yksilön ikäryhmä muuttuu erilaisten siirtymäriittien välityksellä.

Länsimaisessa kulttuurissa ihmisen iät on sijoitettu vertauskuvallisesti elämänkaaren vaiheiksi - vaiheistus tosin on vaihdellut ja nyansoitunut eri tavoin eri aikoina. Siirtymät ikäryhmästä toiseen ovat liukuvia, näyttääpä lapsuuden ja nuoruuden välimaille syntyneen uusi varhaisnuorten ikäryhmäkin. Samoin on keski-ikää ja 
vanhaa ikää jaksoteltu tai ryhmitelty erilaisiin alavaiheisiin. Nuoruuden piteneminen on länsimaissa pitkä trendi, joka liittyy muun muassa ammatillistumiseen, koulutuksen pitenemiseen, aikuisuuden vaatimusten yhä vaikeampaan täyttämiseen tai proosallisesti aikuisten työ- ja kulutusmarkkinoiden tiukempaan sulkeutumiseen uusilta ikäluokilta. Samaan aikaan nuoruus ja nuorekkuus ovat saaneet kulttuurissa ennen näkemättömän symbolisen arvon, kuten Sven-Erik Klinkmann kuvaa kolumnissaan.

Useimpiin eroihin näyttää liittyvän laaja harmaa alue, eron tunnusmerkitön osapuoli: valkoisuus ei ole rotu eikä angloamerikkalaisuus etnos, mies ei ole sukupuoli eikä heterous ole seksuaalinen suuntautuminen; aikuisuus ei ole ikä vaan tylsää, harmaata normaaliutta. Mahtaako yhteenkään toiseen eroon liittyä vastaavaa, symbolisesti yhtä työstettyä ja rikasta utooppisen aluetta kuin ikäeroon liittyvä nuorekkuuden tai ikuisen nuoruuden utopia?

\section{KiRjallisuUS}

HAUTALA, JOUKO 1954: Sumalainen kansanrunoudentutkimus. Suomalaisen Kirjallisuuden Seuran Toimituksia 244. Helsinki: Suomalaisen Kirjallisuuden Seura.

LÖNNROT, ELIAS 1997: Alkulause. - Kanteletar elik.kä Suomen kansan vanhoja lauluja ja virsiä. Suomalaisen Kirjallisuuden Seuran Toimituksia 3. Helsinki: Suomalaisen Kirjallisuuden Seura.

PURHONEN, SEMI 2007: Sukupolvien ongelma. Tutkielma sukupolvien käsitteestä, sukupolvititeoisuudesta ja suurista ikäluokista [online]. - E-thesis - Helsingin yliopiston verkekojulkaisut. $<$ http://urn.fi/URN:ISBN:978-952-10-3833-4> [25.4.2008.]

VAKIMO, SINIKKA 2001: Paljon kokeva, vähän näkyvä. Tutkimus vanhaa naista koskevista kulttuurisista käsityksistä ja vanban naisen elämänkäytännöistä. Suomalaisen Kirjallisuuden Seuran Toimituksia 818. Helsinki: Suomalaisen Kirjallisuuden Seura.

VIRTANEN, MATTI 2001: Fennomanian perilliset. Polïttiset traditiot ja sukeupolvien dynamiikka. Suomalaisen Kirjallisuuden Seuran Toimituksia 831. Helsinki: Suomalaisen Kirjallisuuden Seura.

Dosentti, filosofian tohtori Outi Fingerroos työskentelee Jyväskylän yliopistossa etnologian yliassistenttina ja filosofian tohtori Tuija Hovi Kirkon tutkimuskeskuksessa tutkijana. Filosofian lisensiaatti Merja Leppälahti on folkloristiikan tutkija Turun yliopistossa ja dosentti, filosofian tohtori Helena Saarikoski toimii vapaana tutkijana. 